disintegration of clots seems to have a high mortality and important morbidity. We suspect that cases have often masqueraded under other diagnostic labels. Presentation is usually within 24 hours after thrombolytic treatment, and treatment at this stage with anticoagulation and prostaglandin analogues may be beneficial. We recommend that patients considered for thrombolytic treatment should be examined for conditions associated with intravascular clot. Thus ventricular aneurysm, aneurysm of the aorta or of other large arteries, and mitral valve disease with atrial fibrillation may be contraindications for thrombolysis. We emphasise, however, that patients should not be denied the benefits of myocardial salvage and the potential reduction in mortality that can be achieved with thrombolytic treatment ${ }^{12}$ unless the associated risks are appreciable.

We thank Schering Health Care for supplying iloprost in case 5.

1 Rao AK, Pratt C, Berke A, et al. Thrombolysis in myocardial infarction (TIMI) trial. Phase I: hemorrhagic manifestations and changes in plasma fibrinogen and the fibrinolytic system in patients treated with recombinant tissue plasminogen activator and streptokinase. $\mathcal{A}$ Am Coll Cardiol 1988;11: $1-11$
2 Mathey DG, Schofer J, Kuck Beil U, Kloppel G. Transmural, haemorrhagic myocardial infarction after intracoronary streptokinase. Clinical, angiomyocardial infarction after intracoronary streptokinase.
graphic and necropsy findings. Br Heart 1982 $_{108}$ : $546-51$

3 Bucknall C, Darley C, Flax J, Vincent R, Chamberlain D. Vasculitis complicating treatment with intravenous anisoylated plasminogen streptokinase activator complex in acute myocardial infarction. $\mathrm{Br}$ Heart $\mathcal{f}$ 1988;59:9-11.

4 Rademaker M, Thomas RHM, Provost G, Beacham JA, Cooke ED, Kirby JDT. Prolonged increase in digital blood flow following iloprost infusion in patients with systemic sclerosis. Postgrad Med J 1987;63:617-20.

5 Weinreich DJ, Burke JF, Pauletto FJ. Left ventricular mural thrombi complicating acute myocardial infarction. Ann Intern Med 1984;100:789-94.

6 Stratton JR, Resnick AD. Increased embolic risk in patients with left ventricular thrombi. Circulation 1987:75:1004-11.

7 Pirson Y, Honhon B, Cosyns JP, Van Ypersele C. Cholesterol embolism in a renal graft after treatment with streptokinase. Br Med f 1988;296:394-5.

8 Glassock RJ, Ritz E, Bommer J, Andrassy K, Waldherr R. Acute renal failure, hypertension and skin necrosis in a patient with streptokinase therapy. Am f Nephrol 1984:4:193-200.

9 Lew AS, Cercek B, Hod H, Shah PK, Ganz W. Usefulness of residual plasma fibrinogen after intravenous streptokinase for predicting delay or failure of reperfusion in acute myocardial infarction. Am $\mathcal{F}$ Cardiol 1986;58:680-5.

10 Dejaeger P, Van De Werf F, Vermylen J, De Geest H. Thromboembolic complication after streptokinase therapy of pulmonary emboli. Acto Cardiologica (Brux) 1988;43:61-5.

11 Rademaker $M$, Cooke ED, Almond NE, et al. Comparison of intravenou infusions of iloprost and oral nifedipine in treatment of Raynaud's phenomenon in patients with systemic sclerosis: a double blind randomised study. Br Med f 1989;298:561-4.

12 Julian DG Pentecost BL Chamberlain DA. A milestone for myocardia infarction. BrMed f 1988;297:497-8.

(Accepted 29 September 1989)

\title{
Neuropathology of HIV infection in haemophiliacs: comparative necropsy study
}

\author{
M M Esiri, F Scaravilli, P R Millard, J N Harcourt-Webster
}

Departments of

Neuropathology and

Clinical Neurology,

Radcliffe Infirmary, Oxford

OX2 6HE

M M Esiri, DM, clinical reader in neuropathology

\section{Department of}

Neuropathology, Institute

of Neurology, London

WC1

F Scaravilli, MD, reader

\section{Department of}

Histopathology,

John Radcliffe Hospital,

Oxford

P R Millard, MD, consultant

histopathologist

Department of

Histopathology,

St Stephen's Hospital,

London SW10 9TH

J N Harcourt-Webster, MD,

consultant histopathologist

Correspondence and

requests for reprints to:

Dr Esiri.

BrMed f 1989;299:1312-5

\section{Abstract}

Objective-To discover whether pathological and neuropathological findings at necropsy are different in haemophiliacs and other subjects positive for HIV.

Design-Pathological and neuropathological findings at necropsy were compared in haemophiliacs and non-haemophiliacs, most of them homosexual men.

Setting-Necropsies performed in the south of England.

Subjects-11 Haemophiliacs (mean age 41, range 15-69) and 31 non-haemophiliacs, 29 of whom were homosexual men (mean age 40, range 21-60). AIDS was diagnosed before death in four haemophiliacs and all but one of the non-haemophiliacs.

Main outcome measures-Prevalence of various forms of neuropathology and systemic pathology in the haemophiliacs and non-haemophiliacs, compared with Fisher's exact test.

Results-The prevalences of opportunistic infections of the central nervous system were significantly higher in the non-haemophiliacs (cerebral toxoplasmosis $23 \%$ (7), progressive multifocal leucoencephalopathy $10 \%(3)$, and cerebral cytomegalovirus infection $19 \%(6)$ in the non-haemophiliacs $v$ no cases in the haemophiliacs). The prevalences of fresh and old intracranial haemorrhages and cirrhosis of the liver were significantly higher in the haemophiliacs (fresh intracranial haemorrhage $\mathbf{4 5 \%}$ (5), old intracranial haemorrhage $36 \%(4)$, and cirrhosis of the liver $27 \%$ (3) in the haemophiliacs $v$ no cases in the non-haemophiliacs). The prevalence of neuropathological changes in the non-haemophiliacs was similar to that found in other necropsy series.

Conclusions - The main causes of death in haemophiliacs positive for HIV included intracranial haemorrhage and cirrhosis of the liver. The haemo- philiacs died when the characteristic neuropathological changes associated with HIV infection were at a fairly early stage in their development.

\section{Introduction}

Neuropathological studies in North America and Europe of patients dying of AIDS have shown a variety of changes, including an encephalopathy or encephalitis associated with multinucleated giant cells in $25-30 \%$ of cases. ${ }^{1-5}$ In addition, there may be lesions due to opportunistic infections or lymphomas. In most of the necropsy series reported most cases of infection with HIV occurred in homosexual men and drug abusers. Haemophiliacs with HIV infection acquired from infected blood products have generally formed a small proportion of the total cases reported, and there has been no clear indication of whether the neuropathology in these subjects differs from that in other groups at risk. We present the results of neuropathological examination at necropsy in a series of subjects infected with HIV that included a fairly high proportion of haemophiliacs $(25 \%)$.

\section{Subjects and methods}

We examined brains from 42 subjects known to have had antibodies to HIV. Eleven were haemophiliacs, 29 were known to have been homosexual, one was the husband of a drug addict, and one was a nurse from Zambia. All but one were men. The mean age of the haemophiliacs was 41 years (range 15-69) and that of the non-haemophiliacs 40 years (21-60). The duration for which the haemophiliacs were known to have had HIV antibodies varied between nine and 48 months (mean 31 months) and for the other subjects from nil to 48 months (mean 15 months). Agreed criteria for the clinical diagnosis of AIDS $^{6}$ were met in four of the haemophiliacs and in all but one of the other subjects. 
Of the seven haemophiliacs with no clinical evidence of AIDS, four died of an acute neurological illness diagnosed as intracranial haemorrhage (cases 2, 3, 6, and 7; table I); one developed an acute "locked in" syndrome shortly before death (case 10) and the two others had no neurological symptoms or signs other than longstanding ones related to episodes of intracranial bleeding (cases 4 and 8 ). The haemophiliacs with AIDS had no neurological symptoms or signs, apart from one who had clinical features of an acute intracerebral haemorrhage (case 9). Of the 30 non-haemophiliacs with AIDS, 17 had neurological symptoms at death. Pathological findings outside the central nervous system in the haemophiliacs are summarised in table I.

Brains from all subjects were fixed by suspension in $10 \%$ neutral formalin. After three to eight weeks' fixation coronal or horizontal slices $(1 \mathrm{~cm})$ were made through the cerebrum and hindbrain and any abnormalities detectable with the naked eye were noted and sectioned for microscopy. In addition, multiple samples from the cerebrum, basal ganglia, thalamus, brain stem, and cerebellum were processed for microscopy using routine neuropathological techniques.

Multinucleated giant cell encephalopathy was diagnosed if there were diffuse or focal areas of pallor in myelin stained sections or dissolution of myelin and axons, or both. These features had to be accompanied by multinucleated giant cells and macrophages in the abnormal areas of white matter or in the basal ganglia, thalamus, or brain stem. In some cases there were also sparse lymphocytic infiltrates at the same sites. Opportunistic infections were diagnosed from the characteristic neuropathological features coupled with identification of the pathogens concerned.

Differences between haemophiliacs and nonhaemophiliacs were compared by using Fisher's exact test.

\section{Results}

Neuropathological findings in the two groups are summarised in table II. There were two significant differences in the findings in the central nervous system between the haemophiliacs and the other subjects. Firstly, opportunistic infections (papovavirus causing progressive multifocal leucoencephalopathy, cytomegalovirus, and toxoplasmosis) were present in none of the haemophiliacs but in half of the other subjects $(16(52 \%) ; \mathrm{p}<0.01)$. Secondly, acute intracranial haemorrhage was found in nearly half of the haemophiliacs (45\%) and older intracranial haemorrhage in just over a third $(36 \%)$ but no such haemorrhages were found in the other subjects $(\mathrm{p}<0 \cdot 01)$. In addition, multinucleated giant cell encephalopathy was found in only one haemophiliac but
TABLE II -Numbers (percentages) of haemophiliacs and other subjects positive for HIV with neuropathological changes at necropsy

\begin{tabular}{|c|c|c|}
\hline Condition & $\begin{array}{l}\text { Haemophiliacs } \\
\qquad(\mathrm{n}=11)\end{array}$ & $\begin{array}{l}\text { Others } \\
(n=31)\end{array}$ \\
\hline \multicolumn{3}{|l|}{ Opportunistic infections } \\
\hline Cerebral toxoplasmosis & 0 & $7(23)$ \\
\hline Progressive multifocal leucoencephalopathy & 0 & $3(10)$ \\
\hline Cerebral cytomegalovirus infection & 0 & $6(19)$ \\
\hline \multicolumn{3}{|l|}{ Vascular disease } \\
\hline Fresh intracranial haemorrhage & $5(45)^{\star \star}$ & 0 \\
\hline Old intracranial haemorrhage & $4(36)^{\star}$ & 0 \\
\hline Brain stem infarction & $1(9)$ & 0 \\
\hline \multicolumn{3}{|l|}{ Other } \\
\hline Multinucleate giant cell encephalopathy & $1(9)$ & $8(26)$ \\
\hline Diffuse myelin pallor & $3(27)$ & $3(10)$ \\
\hline Lymphocytic perivascular infiltrates in meninges & & \\
\hline $\begin{array}{l}\text { or brain, or both } \\
\text { Microglial nodules }\end{array}$ & $\begin{array}{l}2(18) \\
4(36)\end{array}$ & $\begin{array}{l}3(10) \\
3(10)\end{array}$ \\
\hline
\end{tabular}

${ }^{\star} \mathrm{p}<0.01,{ }^{\star \star} \mathrm{p}<0.001$ with Fisher's exact test.

in eight of the 31 other subjects (26\%). This trend may be important, even though it was not significant in this small series.

Microglial nodules without cytomegalovirus inclusions or antigen detectable by immunocytochemistry, mild perivascular lymphocytic infiltrates in leptomeninges and brain, and diffuse myelin pallor with or without reactive astrocytosis but not associated with multinucleated giant cells were found more often in the haemophiliacs than in the non-haemophiliacs, but the differences were not significant. Outside the nervous system cirrhosis of the liver was more common in the haemophiliacs than in the other subjects $(p<0.03$; table III). Kaposi's sarcoma was not seen in any haemophiliac but was present in six of the other subjects, again a noteworthy difference, though not significant.

TABLE III-Numbers (percentages) of haemophiliacs and other subjects positive for HIV with systemic pathological changes

\begin{tabular}{lcc}
\hline & $\begin{array}{c}\text { Haemophiliacs } \\
(\mathrm{n}=11)\end{array}$ & $\begin{array}{c}\text { Others } \\
(\mathrm{n}=29)\end{array}$ \\
\hline Kaposi's sarcoma & 0 & $6(21)$ \\
Pneumocystis pneumonia & $2(18)$ & $6(21)$ \\
Other opportunistic infections & $1(9)$ & $6(21)$ \\
Cirrhosis of liver & $3(27)^{\star}$ & 0 \\
Lymphadenopathy or hypoplasia & $2(18)$ & $5(17)$ \\
Lymphoma & 0 & $3(10)$ \\
\hline
\end{tabular}

${ }^{\star} \mathrm{p}<0.03$ with Fisher's exact test.

\section{Discussion}

Price et al divided the histopathological abnormalities in patients with the AIDS dementia complex, with which multinucleated giant cell encephalopathy is closely associated, into three grades of severity. Group 1 , the most severe, contained an estimated quarter of all patients at necropsy and included subjects

TABLE I-Clinical details of and pathological and neuropathological findings at necropsy in 11 haemophiliacs

\begin{tabular}{|c|c|c|c|c|c|c|c|}
\hline $\begin{array}{l}\text { Case } \\
\text { No }\end{array}$ & Sex & $\begin{array}{c}\text { Age } \\
\text { (years) }\end{array}$ & $\begin{array}{c}\text { Time known } \\
\text { to have HIV } \\
\text { antibodies } \\
\text { (months) }\end{array}$ & $\begin{array}{l}\text { Clinical } \\
\text { AIDS }\end{array}$ & $\begin{array}{l}\text { Neurological } \\
\text { symptoms } \\
\text { at death }\end{array}$ & Pathological findings outside central nervous system & Neuropathological findings in central nervous system \\
\hline 1 & $M$ & 69 & 16 & Yes & No & $\begin{array}{l}\text { Pneumocystis pneumonia; cytomegalovirus pneumonitis; } \\
\text { candidiasis }\end{array}$ & $\begin{array}{l}\text { Microglial nodules; diffuse myelin pallor; old cerebellar } \\
\text { haemorrhage }\end{array}$ \\
\hline 2 & M & 34 & 9 & No & Yes & Liver cirrhosis & Acute cerebellar haemorrhage; old right occipital haemorrhage \\
\hline 3 & M & 34 & 18 & No & Yes & Lung and splenic abscesses & $\begin{array}{l}\text { Acute right intracerebral haemorrhage; mild lymphocytic } \\
\text { meningitis or encephalitis, or both; microglial nodules }\end{array}$ \\
\hline 4 & $M$ & 15 & 30 & No & No & Aplastic anaemia; lymphoid hypoplasia & $\begin{array}{l}\text { Diffuse myelin pallor; microglial nodules; old right intracerebral } \\
\text { haemorrhage }\end{array}$ \\
\hline 5 & M & 53 & 28 & Yes & No & Pneumocystis pneumonia; liver cirrhosis & Nothing abnormal \\
\hline 6 & M & 44 & 38 & No & Yes & Bronchopneumonia & $\begin{array}{l}\text { Acute intracerebral and ventricular haemorrhage; chronic right } \\
\text { subdural haemorrhage }\end{array}$ \\
\hline 7 & $M$ & 18 & 40 & No & Yes & Nothing abnormal & $\begin{array}{l}\text { Acute subarachnoid haemorrhage; mild lymphocytic meningitis } \\
\text { or encephalitis, or both }\end{array}$ \\
\hline 8 & $M$ & 63 & 34 & No & No & Liver cell carcinoma; cirrhosis & Diffuse myelin pallor \\
\hline 9 & M & 44 & 31 & Yes & Yes & Nothing abnormal & Acute left intracerebral haemorrhage; microbial nodules \\
\hline 10 & $M$ & 17 & 45 & No & Yes & Bronchopneumonia & Brain stem infarction; multinucleated giant cell encephalopathy \\
\hline 11 & M & 59 & 48 & Yes & No & $\begin{array}{l}\text { Bronchopneumonia; retroperitoneal haematoma; lymphoid } \\
\text { hypoplasia }\end{array}$ & Anoxic foci caudate nuclei \\
\hline
\end{tabular}


with moderate to severe clinical symptoms of AIDS dementia complex and all subjects with multinucleated giant cells. Group 2 contained an estimated half of all subjects with AIDS at necropsy and included subjects with mild to moderate symptoms of AIDS dementia complex. These brains showed mild to moderate diffuse myelin pallor. Group 3 consisted of the remaining quarter of all patients at necropsy in whom clinical evidence of AIDS dementia complex was lacking and whose brains showed absent or mild diffuse myelin pallor. The cases of HIV infection in non-haemophiliacs with clinical AIDS included in our study can be distributed in all three of these categories, but all but one of the haemophiliacs would fall into group 3 (those with clinical AIDS) or occupy a fourth category of pre-AIDS (those not recognised as having AIDS).

A review of the published reports on the neuropathology of AIDS in haemophiliacs confirms the low prevalence of HIV encephalopathy with multinucleated giant cells and opportunistic infections in the nervous system. In another recently reported series no case of multinucleated giant cell encephalopathy was found among eight haemophiliacs positive for HIV studied at necropsy ${ }^{8}$ Cytomegalovirus encephalitis has been reported in only two cases, ${ }^{910}$ crytoptococcosis in one, ${ }^{11}$ and progressive multifocal leucoencephalopathy in one. ${ }^{12}$ Two cases with neurological symptoms attributed to HIV infection but without neuropathological examination were also reported by Rahemtulla et $a l,{ }^{13}$ and a case of clinical cerebral toxoplasmosis without neuropathology was reported by Jones et al. ${ }^{1+}$ The rarity of opportunistic infections in the central nervous system and elsewhere in haemophiliacs is in keeping with many of them dying at an earlier (pre-AIDS) stage in the development of HIV associated immunodeficiency than do most subjects with HIV infection. Consistent with this suggestion is Hilgartner's view that the pattern of disease due to HIV infection in haemophiliacs differs from that in other groups at high risk, ${ }^{15}$ and the observation of Darby et al that a substantial burden of fatal disease occurs among haemophiliacs who are positive for HIV and not formally diagnosed as having AIDS. ${ }^{16}$ If our cases of haemophilia are representative of others much of this fatal disease would seem to be accounted for by cerebrovascular and liver disease.

There are several possible reasons why haemophiliacs positive for HIV die before the development of full blown AIDS and its usual neurological sequelae, which include multinucleated giant cell encephalopathy. Firstly, they are at high risk of developing fatal intracranial haemorrhage as a consequence of their deficiencies in clotting factors. There is no clear evidence that infection with HIV enhances this risk, although it does cause thrombocytopenia in some subjects, ${ }^{17-19}$ which might be expected to aggravate the tendency to bleed. Thrombocytopenia in haemophiliacs infected with HIV has a particularly poor prognosis when combined with HIV antigenaemia and a low titre of p24 antibody. ${ }^{15}$ Earlier studies in haemophiliacs before the appearance of HIV infection and AIDS indicated that $29 \%$ died of intracranial haemorrhage..$^{20}$ In our series $45 \%$ of the haemophiliacs died of intracranial haemorrhage, but this rate is not significantly higher than that expected in such a small series.

The recent incidence of clinically diagnosed fatal intracranial haemorrhage in haemophiliacs positive for $\mathrm{HIV}$ in the United Kingdom is no higher than that in haemophiliacs with no antibodies to the virus (C R Rizza, personal communication).

A second possible reason why haemophiliacs positive for HIV might die before developing full blown AIDS is the risk that they share with all haemophiliacs of developing diseases associated with blood trans- fusion-for example, hepatitis and cirrhosis caused by hepatitis viruses. Two of the haemophiliacs in our series had cirrhosis and another developed hepatocellular carcinoma as well as cirrhosis. A third contributory factor could be that changes occur that accelerate the development of AIDS in subjects at risk other than haemophiliacs. In our series Kaposi's sarcoma was present in $21 \%$ of non-haemophiliacs but none of the haemophiliacs, which has been seen before. ${ }^{21-23}$

Multinucleated giant cell encephalopathy in patients with AIDS correlates most closely with the presence of HIV in the brain. ${ }^{17}$ Studies of cerebrospinal fluid in subjects infected with HIV suggest that the virus reaches the central nervous system and causes oligoclonal IgG and HIV specific local antibody to be produced well before neurological symptoms or signs attributable to HIV infection develop. . $^{24-26}$ The microglial nodules, diffuse myelin pallor, and perivascular lymphocytic cuffing in meninges and brain found in some of our subjects and described by others are non-specific features that may or may not reflect the presence of HIV in the brain or meninges.

Our results show that haemophiliacs positive for HIV antibody constitute a group of subjects that provide an opportunity for the study at necropsy of the early stages of HIV induced changes in the nervous system.

We thank Dr C R Rizza and the staff of the Infectious Diseases Unit, Churchill Hospital, Oxford, for their clinical collaboration and permission to publish details of patients under their care. Mr M Hawkins provided statistical advice. This study received financial support from the United Kingdom Medical Research Council.

1 Navia BA, Cho E-S, Petito CK, Price RW. The AIDS dementia complex. II Neuropathology. Ann Neurol 1986;19:525-35.

2 Petito CK, Cho E-S, Lemann W, Navia BA, Price RW. Neuropathology of acquired immunodeficiency syndrome (AIDS): an autopsy review. f Neuropathol Exp Neurol 1986;45:635-46.

3 Budka H, Costanzi G, Cristina S, et al. Multinucleated giant cells in brain: hallmark of the acquired immune deficiency syndrome (AIDS). Acto Neuropathol (Berl) 1986;69:253-8.

4 Gonzales MF, Davis RL. Neuropathology of acquired immunodeficiency syndrome (AIDS). Neuropathol Appl Neurobiol 1988;14:345-63.

5 Gray F, Gherardi R, Keohane C, Favolini M, Sobel A, Poirier J. Pathology of the central nervous system in 40 cases of acquired immune deficiency the central nervous system in 40 cases of acquired imme (AIDS). Neuropathol Appl Neurobiol 1988;14:365-80.

6 Centers for Disease Control, Atlanta. Revision of the CDC surveillance case definition for acquired immunodeficiency syndrome. MMWR 1987;36: $1-15 S$.

7 Price RW, Brew B, Sidtis J, Rosenblum M, Schek AC, Cleary P. The brain in AIDS: central nervous system HIV-1 infection and AIDS dementia complex. Science 1988;239:586-92.

8 Lantos PL, McLaughlin JE, Scholtz CL, Berry CL, Tighe JR. Neuropathology of the brain in HIV infection. Lancet 1989;i:309-10.

9 Epstein LG, Sharer LR, Joshi VV, Fojas MM, Koenisberger MR, Oleske JM Progressive encephalopathy in children with acquired immune deficiency syndrome. Ann Neurol 1985;17:488-96.

10 Sharer LR, Epstein LG, Cho E-S, et al. Pathologic features in AIDS encephalopathy in children: evidence for LAV/HTLVIII infection of brain Hum Pathol 1986;17:271-84.

11 Rosenberg S, Lopes MBS, Tsanaclis AM. Neuropathology of acquired immunodeficiency syndrome (AIDS). An analysis of 22 Brazilian cases. 7 Neurol Sci 1986;76:187-98.

12 Ries F. Progressive multifokale leukoenzephalopathie bei Haemophilic A. Besteht ein Zusammenhaug mit AIDS. Nervenarzt 1986;56:442-8.

13 Rahemtulla A, Durrant STS, Hows JM. Subacute encephalopathy associated with human immunodeficiency virus in haemophilia A. Br Med f 1986;293: 993.

14 Jones $\mathrm{P}$, Hamilton PJ, Bird G, et al. AIDS and haemophilia: morbidity and mortality in a well defined population. Br Med f 1985;291:695-9.

15 Hilgartner MW. AIDS and hemophilia. N Engl F Med 1987;317:1153-4.

16 Darby SC, Rizza CR, Doll R, Spooner RJD, Stratton IM, Thakrar B. Incidence of AIDS and excess mortality associated with HIV in haemophiliacs in the United Kingdom: report on behalf of the directors of haemophilia centres in the United Kingdom. Br Med $\mathcal{F}$ 1989;298:1064-8.

17 Morris L, Distenfeld A, Amorosi E, Karpatkin S. Autoimmune thrombocytopenic purpura in homosexual men. Ann Intern Med 1982;96:714-7.

18 Abrams DI, Kiprov DD, Goedert JJ, et al. Antibodies to human T-lymphotropic virus type III and development of acquired immune deficiency syndrome in homosexual men presenting with immune thrombocytopenia. Ann Intern Med 1986;104:47-50.

19 Desforges J. Mark EJ Case record 41-1987. N Engl Y Med 1987;317:946-53.

20 Rizza CR, Spooner RJD. Treatment of haemophilia and related disorders in Britain and Northern Ireland during 1976-80: report on behalf of the Britain and Northern Ireland during 1976-80: report on behalf of the
directors of haemophilia centres in the United Kingdom. Br Med directors of hae

21 Guinan ME, Thomas PA, Pinsky PF, et al. Heterosexual and homosexual patients with acquired immunodeficiency syndrome: a comparison of surveillance, interview and laboratory data. Ann Intern Med 1984;100:213-8. 

immunodeficiency syndrome in patients with hemophilia. Ann Intern Med 1984:100:499-504

23 Cohn DL, Judson FN. Absence of Kaposi's sarcoma in hemophiliacs with the acquired immunodeficiency syndrome. Ann Intern Med 1984;101:401.

24 Elovaara I, Iivanainen $M$, Valle S-L, Suni J, Tervo T, Lahdevirta J. CSF protein and cellular profiles in various stages of HIV infection related to neurological manifestations. F Neurol Sci 1987;78:331-42.
25 Andersson MA, Bergstrom TB, Blomstrand C, Hermodsson SH, Hakansson C, Lowhagen G-B E. Increasing intrathecal lymphocytosis and immunoC, Lulin $G$ production in neur ing globulin $G$ production in neurolo

26 Resnick L, Berger JR, Shapshak P, Tourtellotte WW. Early penetration of the blood-brain-barrier by HIV. Neurology 1988;38:9-14.

(Accepted 21 September 1989)

\section{Blood splashes: an underestimated hazard to surgeons}

\author{
Stephen Brearley, Laura J Buist
}

\section{Walsgrave Hospital, \\ Coventry CV2 2DX \\ Stephen Brearley, FRCS, surgical senior registrar \\ Laura J Buist, FRCS, surgical registrar}

Correspondence to: $\mathrm{Mr}$ Stephen Brearley, Surgical

Department, East

Birmingham Hospital,

Bordesley Green,

Birmingham B9 5ST.

BrMed f 1989;299:1315

Recent evidence confirms the widespread belief that hepatitis $\mathrm{B}$ virus may be transmitted through the and there are theoretical grounds for thinking that HIV surgeons' routinely use eye protection while operating, but in hospitals in the United States protecting the eyes is becoming the norm in centres where the prevalence surgeons' eyes are splashed with body fluids. We counting the number of splashes of blood on our conjunctiva (S Polakoff, personal communication), might also be acquired in this way. In Britain few of HIV carriage is high. ${ }^{1}$ It is not known how often attempted to assess the risk of infection by this route by spectacle lenses at the end of each of a consecutive series of operations.

\title{
Methods and results
}

Both of us always wear spectacles when operating. Over three months we recorded the number of splashes of blood on our glasses after each operation and then cleaned the lenses carefully before the next operation. The nature and duration of each operation were recorded. Data were collected from a consecutive series of 257 operations.

Overall, we found at least one splash of blood after 64 operations $(25 \%)$, the number of splashes ranging from one to 40 , median four. More than 10 splashes

Incidence of blood splashes on spectacles during operations

\begin{tabular}{lcc}
\hline Operations & No performed & Spectacles splashed \\
\hline Type: & & \\
Arterial & 25 & 11 \\
Gastrointestinal & 40 & 24 \\
Other & 192 & 29 \\
Duration: & & \\
< $30 \mathrm{~min}$ & 151 & 11 \\
$30-120 \mathrm{~min}$ & 77 & 35 \\
$>120 \mathrm{~min}$ & 29 & 18 \\
\hline
\end{tabular}

\section{Oral contraceptives and diabetes mellitus}

\author{
Philip C Hannaford, Clifford R Kay
}

Royal College of General

Practitioners, Manchester Research Unit,

Manchester M20 0TR

Philip C Hannaford, MRCGP, clinical research fellow

Clifford R Kay, FRCGP, director

BrMed f 1989;299:1315-6
Although it has been shown that in some women glucose tolerance deteriorates when they use oral contraceptives, ${ }^{1.3}$ there is uncertainty about the clinical importance of these changes. In particular, do they predispose users of the contraceptive pill to an increased risk of clinical diabetes mellitus? An earlier report suggested that pill users were not at risk. ${ }^{4}$ It has been argued, however, that an increased risk may become were present on eight occasions. There was a mean of 1.3 splashes per operation or 5.0 per case in which contamination occurred. We were aware of the contamination during the operation on only three occasions. The incidence of contamination varied with the type of operation and its duration (table). The mean number of splashes acquired per hour of operating in cases taking up to 30 minutes was half that in cases taking two hours or more $(0.94 v 1.9)$. The incidence of contamination was slightly higher for one surgeon than for the other $(28 \% v 22 \%)$, owing to a higher proportion of long or complex operations.

\section{Comment}

In general surgery fine drops of blood bombard the area around the surgeon's eyes during a quarter of operations. Both the incidence and the rate of contamination are higher in complex and long operations, but contamination can occur during minor procedures. We do not think that we are unusually messy surgeons, and the fact that we both had similar rates of contamination suggests that the results may be typical of general surgery and perhaps of all types of surgery. Most of the blood splashes were minute, and we were unaware of them in all but three cases. Such splashes are unlikely to trigger a reflex blink when hitting the eye, which is unlikely anyway to prevent infection occurring.

The surface area of spectacle lenses is substantially larger than that of the palpebral fissure, and only a proportion of the splashes that were picked up on the lenses would otherwise have entered the eye. Nevertheless, the incidence of deposits of blood was high. Each surgeon must decide on the basis of the available data whether the risk of infection is sufficient to justify wearing eye protection while operating. As the number of HIV carriers in England and Wales is estimated to be $36000-148000^{2}$ we think that eye protection should become routine. Unfortunately, conventional spectacles provide only partial protection: several of the blood splashes were on the inner surfaces of our lenses.

1 Sim AJW, Dudley HAF. Surgeons and HIV. Br Med f 1988;296:80. 2 Wilkie AD. Forecasting AIDS using an actuarial model. In: Cox D, Anderson $\mathrm{RM}$, Johnson AM, et al. Short-term prediction of HIV infection and AIDS in England and Wales. Report of a working group. London: HMSO, 1988.

(Accepted 14 September 1989

apparent only after prolonged observations of women who have used the pill for long periods of time. ${ }^{3} \mathrm{We}$ present the latest findings from the Royal College of General Practitioners' oral contraception study, using data available at May 1989.

\section{Patients, methods, results}

Over a 14 month period starting in May 1968, 1400 general practitioners throughout the United Kingdom recruited 23000 women who were using the contraceptive pill and 23000 who had never used it. At six month intervals thereafter the doctors recorded for each woman still under observation details of any oral contraceptives prescribed and all reported episodes of morbidity. These analyses are based on all cases of 